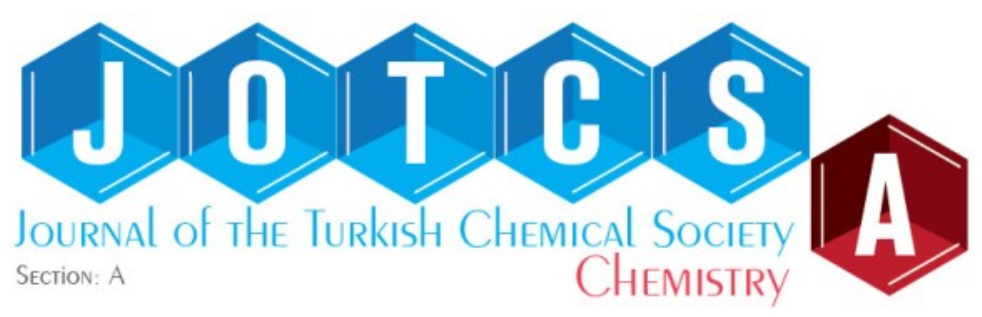

\section{Characterization of the Alphabet Reform Painting}

\section{YIIdiz CAKMAK ${ }^{1}$, Recep KARADAG ${ }^{2,3 *}$, Nilhan KAYAMAN APOHAN ${ }^{4}$ D,} Ömer Yiğit ARAL ${ }^{1}$ and Emrah CAKMAKCI ${ }^{4}$ D

${ }^{1}$ Department of Conservation and Restoration of Artworks, Faculty of Fine Arts, Mimar Sinan Fine Arts University, Bomonti Campus, Istanbul, Turkey

${ }^{2}$ Department of Fashion and Textile Design, Faculty of Fine Arts, Istanbul Aydın University, Florya Campus, Istanbul, Turkey

${ }^{3}$ TCF (Turkish Cultural Foundation) Istanbul, Turkey

${ }^{4}$ Department of Chemistry, Faculty of Science and Literature, Marmara University, Göztepe Campus, Istanbul, Turkey

Keywords: Oil paintings, FTIR-ATR, SEM, HPLC, restoration.

Submitted: October 20, 2020. Accepted: January 05, 2021.

Cite this: Cakmak Y, Karadag R, Kayaman Apohan N. Characterization of the Alphabet Reform Painting. JOTCSA. 2021;8(1):249-62.

DOI: https://doi.org/10.18596/jotcsa.813787.

*Corresponding Author, Email: recepkaradag@aydin.edu.tr / GSM: +90 5325250282.

\section{INTRODUCTION}

There are a limited number of art pieces that survived to this day. It is inevitable that eventually there have been deteriorations or flaking on these pieces of art. Conservator-restorers are trying to restore these alterations developed over time. Restoration practices may be different for each art specimen. The successful restoration of artworks requires an in-depth analysis of the pieces. For instance, with the analysis of old paintings so much information can be attained such as the pigments used in the piece of art and changes that may occur in these pigments over time (1-6), organic and inorganic substances (7-11), the binders (12-13), the areas with retouches or patches on these pieces, the areas with varnish, structural deteriorations (such as cracking, flaking, peeling, and tearing) (14-15), painting technique of the artist (16) and the types of the varnish (17-19) or the canvas that were used (such as silk, linen, hemp, cotton, jute) (20) which are of great importance for the restoration of these paintings. One can even have an idea about the palette of the artist given that he or she has the chance to analyze several pieces of art that belonged to that artist (21). 
Today, many different methods are used in the analysis for restoration and preservation of artworks that are a part of cultural heritage in many countries around the world.

Fourier transform infrared spectroscopy (FTIR) and scanning electron microscopy, and energy dispersive x-ray spectroscopy (SEM-EDX) have proven themselves to be efficient methods for analysis in scientific examination of works of art over a long period of time (11).

Identification of pigments in artefacts can be a source of valuable information in concern with conversation and art history of the object. Numerous studies on the identification of pigments by FTIR analysis can be found in literature (2-5, 21-26). Regardless of the fact that many inorganic pigments such as ultramarine blue, lead white, malachite and Prussian blue fall into mid-IR region with their characteristic absorption bands, there are many that either do not absorb in that region at all or have absorptions that are at the low wave number end of the region and are not characteristic enough. However, through an extensive attenuated total reflectance - fourier transform infrared (ATR-FTIR) study, it was found that historically most widespread inorganic white, yellow, blue, green, brown and black pigments could be differentiated by examining their vibration bands in the region of $550-230 \mathrm{~cm}^{-1}$ (22).

High Performance Liquid Chromatography (HPLC) is also another useful technique for the used for the characterization of artworks. Many objects within a cultural heritage site may contain organic or inorganic materials. Many researchers have used HPLC analysis method to separate into components and to determine the dyestuff in the artwork (8-10, $27,28)$.

These techniques along with others were used extensively in many studies for the characterization of old paintings. For instance, Jana Zelinska et al., investigated the main altar of the St. James Church in Slovakia (7). 25 inorganic pigments, substrate and organic binder samples which were taken from the wood panel were identified using FTIR, SEM-EDS and optical microscopy. FTIR findings led them to conclude that linseed oil was used as a binder whereas SEM-EDX results revealed the presence of azurite, chalk, and lead white (7).

Thiago G. Costa and his friends have examined Louis-Auguste's five paintings. They used UVinduced visible luminescence, SEM-EDX and FTIR spectroscopic techniques. As a result of FTIR analysis, they found carbonates, sulfates, alumina silicates, iron oxides, and Prussian blue as pigments and they found that an oil-based binder was used. According to EDX results, $\mathrm{Pb}$ element was found in all samples (15).
Milene Gil et al., studied Jose de Escovar's panel and mural painting by FTIR, SEM-EDX and technical photography (ultraviolet fluorescence-visibleInfrared) methods. They found Fe, lead white, red lead oxide, red mercury sulfide, calcium hydroxide, titanium, copper, zinc, and sulfur. They have identified the presence of an oil binder by the bands at $2926 \mathrm{~cm}^{-1}, 2854 \mathrm{~cm}^{-1}$ and $1703 \mathrm{~cm}^{-1}$ as a result of FTIR analysis and they have attained information about the artist's painting techniques (16).

In another research, Thiago G. Costa and his friends investigated the painting called "Primeira Missa no Brasil" which was originally made by Victor Meirelles in 1860 and its replica by Sebastiao Vieira Fernandes in 1929. This painting was also analyzed with FTIR, EDX and UV-induced visible luminescence methods. They identified the presence of prussian blue, lithopone, lead white, chrome yellow, cobalt blue pigments in the paintings. FTIR and EDS analyses showed a correlation between the elemental composition of pigments used by Meirelles and Fernandes, especially for lead (29).

In this work, we aimed to characterize the pigments and the binder of the Alphabet Reform painting. The painting was introduced to the Mimar Sinan Fine Arts University from the Ministry of Interior of Republic of Turkey to be restored. This painting was made by Nazmi Ziya GURAN who was influenced by the impressionist movement in Paris and who liked to reflect the opposite colors side by side, in 1933. This painting is of great importance for the history of Turkey for it shows Ataturk introducing the new alphabet reform to public. FTIR-ATR, SEM-EDX, and HPLC methods were used to characterize this painting.

\section{MATERIALS AND METHODS}

\section{Materials}

Purpurin and alizarin reference samples, and dimethylformamide were purchased from Sigma Aldrich. Acetonitrile, trifluoroacetic acid, hydrogen chloride, and methanol were purchased from Merck. The painting was obtained from the Ministry of Interior of Republic of Turkey.

\section{Sample Collection}

Samples were taken with a scalpel from paintings (11 samples) and also from the canvas. Samples (S1, S2, S3, S4, S5, S6, S7, S8, S9, S10 and S11) taken from the parts of the painting marked in Figure 1 (S1-S11) were examined. 


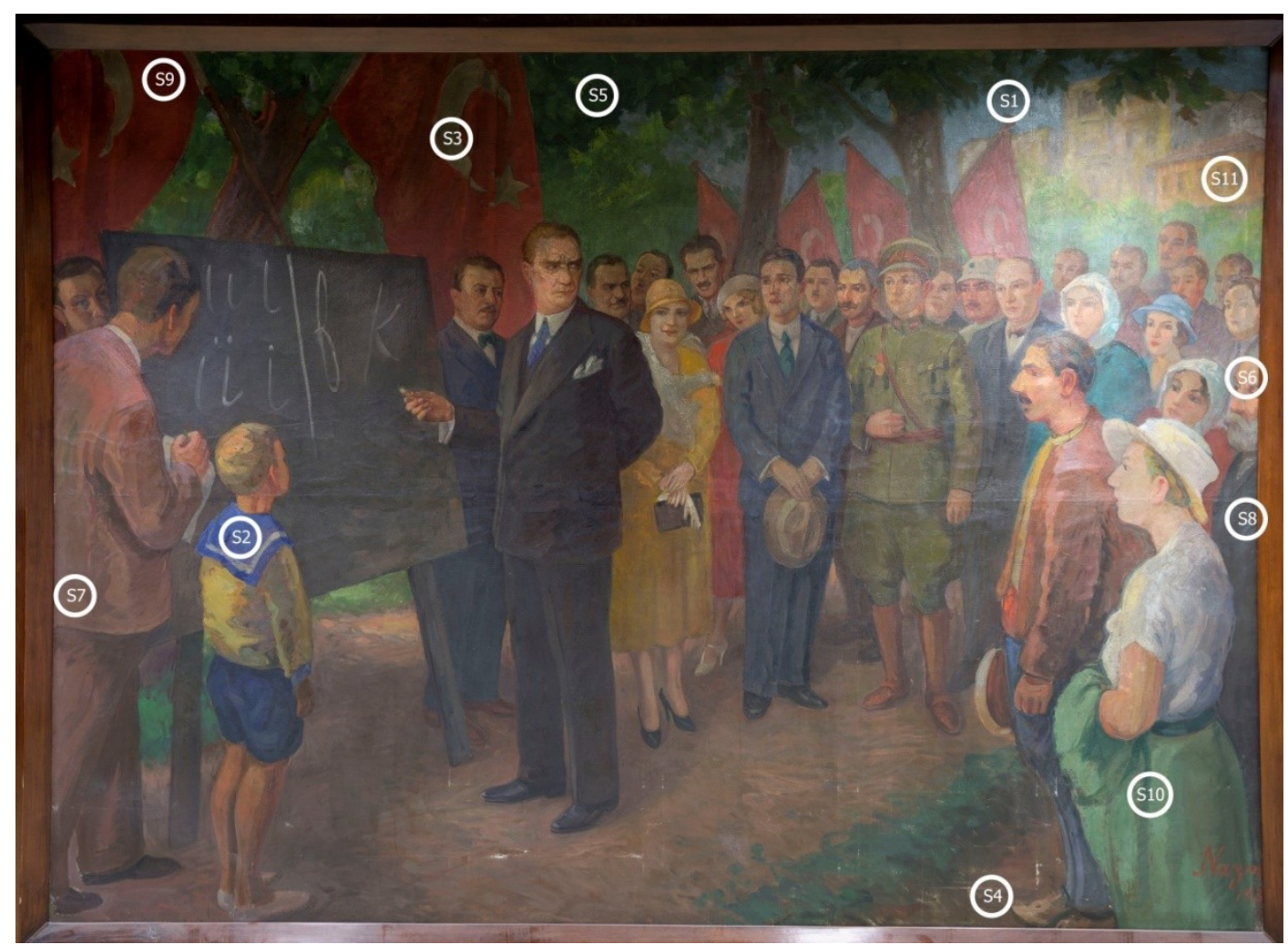

Figure 1. Alphabet Revolution oil paint (by the artist Nazmi Ziya GURAN, 1933).

\section{Infrared-UV Imaging of the Painting}

Infrared and UV authentications were as described in earlier reports $(13-16,30-31)$. Ambient light photograph of the oil painting was taken using a
Canon 5D Mark III camera. Infrared and ultraviolet images were acquired with an OptoLab camera for the documentation process. The images are shown in Figure $2 \mathrm{a}$ and $2 \mathrm{~b}$, respectively.
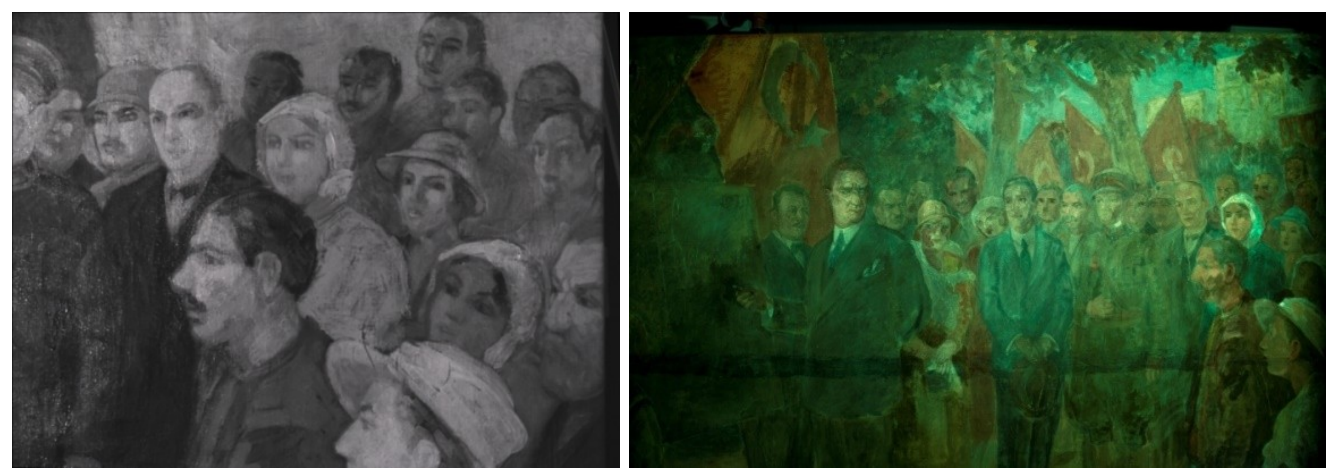

Figure 2. a) IR image (left) and b) UV image (right) of Alphabet Revolution oil paint.

\section{Color Measurements}

The color measurements were as described in earlier reports (32-35). The L*, a* and $b^{*}$ values for the paintings were measured with a Konica Minolta CM 700d spectrophotometer.

\section{HPLC}

The HPLC analysis of the pigments was performed as described in earlier reports (36-39). Acetonitrilewater and water-trifuluoroacetic acid were used as the mobile phase. Purpurin and alizarin were used as references.

\section{SEM-EDX}

SEM-EDX analysis was performed according to an earlier work (34). A Tescan Vega 3 Easy probe SEM with a Bruker 410-M EDX detector and Esprit 1.9 software was used to characterize the morphology of the canvas and other components. SEM-EDX instrumental conditions were a working distance of 8.05-16 $\mathrm{mm}$ and energies of $5-20 \mathrm{kV}$ at a magnification of 100 to 800 . Back scatter detectors were used for secondary electrons with a $30 \mathrm{~s}$ collection time. 


\section{FTIR-ATR}

The FTIR-ATR analysis was conducted as described in earlier reports (40-42). For the analyses of pigments and binders, the ATR-FTIR technique was applied. The analyses were performed with UATR Accessory for Spectrum Two, Diamond (1 Reflection) FTIR spectrometer (Perkin Elmer Diamond /ZnSe). A total of 60 scans were collected in the $4000-400$ $\mathrm{cm}^{-1}$ spectral range, while the resolution employed was $4 \mathrm{~cm}^{-1}$.

\section{RESULTS AND DISCUSSION}

\section{Color Analysis}

The color measurement results supply an important information of the color palette of the artist and it is vital for restorative purposes. During the restoration process, the color palette can be prepared according to the $L^{*}, a^{*}$ and $b^{*}$ values of the painting. Here $L^{*}$ expresses white or black color (0-100); a* expresses red $\left(a^{>} 0\right)$ or green $\left(a^{<} 0\right)$ color and $b^{*}$ expresses yellow $\left(b^{>} 0\right)$ or blue $\left(b^{<} 0\right)$ color. The color measurement results of the painting samples with the CIE L*a*b* are shown in Table 1 . When restorers and conservators need to restore artworks, these values can be used $(18,43,44)$.

\section{SEM-EDX Analysis}

In order to determine the elemental components of cultural heritage artifacts, SEM-EDX technique is used. SEM images were obtained for the samples taken from the predetermined areas of the painting shown in Figure 1. Also SEM-EDX measurements were carried out. SEM image that belongs to the canvas of the painting is shown in Figure 3 . It is seen that the canvas has fibers from plant origin either from flax or hemp (45). FTIR analysis was also carried out on the same canvas and standard flaxseed fibers as shown in Figure 4. As a result of comparison between the canvas and standard flax fibers, it was seen that the band are in compliance with each other and it was decided that canvas was made of flax. According to the results of element analysis for the oil painting samples shown in Table 2 , the main elements were found in these samples are $\mathrm{Pb}, \mathrm{Cd}, \mathrm{Ba}, \mathrm{Zn}, \mathrm{Fe}$ and $\mathrm{Al}$ metals.
Table 1. Color measurement results of all samples.

$\begin{array}{llll}\text { Sample } & \mathbf{L}^{*} & \mathbf{a}^{*} & \mathbf{b} * \\ \text { S1 } & 60.68 & -8.03 & -2.65 \\ \text { S2 } & 40.95 & 1.51 & -25.51 \\ \text { S3 } & 43.11 & 3.53 & 11.07 \\ \text { S4 } & 34.80 & 2.87 & 7.00 \\ \text { S5 } & 38.42 & -12.26 & 12.50 \\ \text { S6 } & 56.81 & 16.90 & 27.41 \\ \text { S7 } & 40.20 & 6.01 & 8.30 \\ \text { S8 } & 31.29 & -1.82 & 1.64 \\ \text { S9 } & 32.91 & 14.44 & 7.99 \\ \text { S10 } & 41.41 & -10.25 & 12.39 \\ \text { S11 } & 59.28 & 7.87 & 20.12\end{array}$

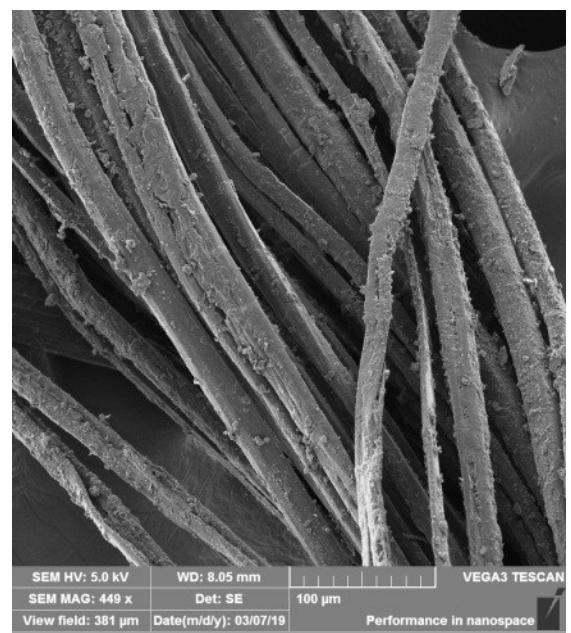

Figure 3. SEM image of the canvas in the Alphabet Revolution oil paint.

\section{FTIR-ATR Analysis}

FTIR was used to characterize the molecular composition of the selected paint samples and gain some information on the degree of hydrolysis of the paint. IR spectra of all samples are presented in Figure 5. The main bands detected in the FTIR-ATR spectra of the samples are summarized in Table 3. It can be seen from the FTIR spectra of the samples that the samples have organic and inorganic components which mean that the samples contain pigments and binder. Based on the FTIR data the binder of the painting was identified as linseed oil while it is thought that dammar resin was used as a varnish. The FTIR spectrum of reference linseed oil is presented in Figure 6 . When Table 3 and the FTIR spectrum of the reference linseed oil in this figure are examined, the presence of common bands (2900-2800 cm $\mathrm{cm}^{-1}, 1700-1750 \mathrm{~cm}^{-1}, 1450-1550 \mathrm{~cm}^{-1}$, 1000-1200 $\mathrm{cm}^{-1}$ ) indicated that the binder in the samples is linseed oil. According to IR results of all samples -except canvas; the surface the painting layer is thought that covered by dammar varnish, as it is indicated by main absorption bands at 1700$1750,1450-1550,1350-1400 \mathrm{~cm}^{-1}(13,17-18)$. 


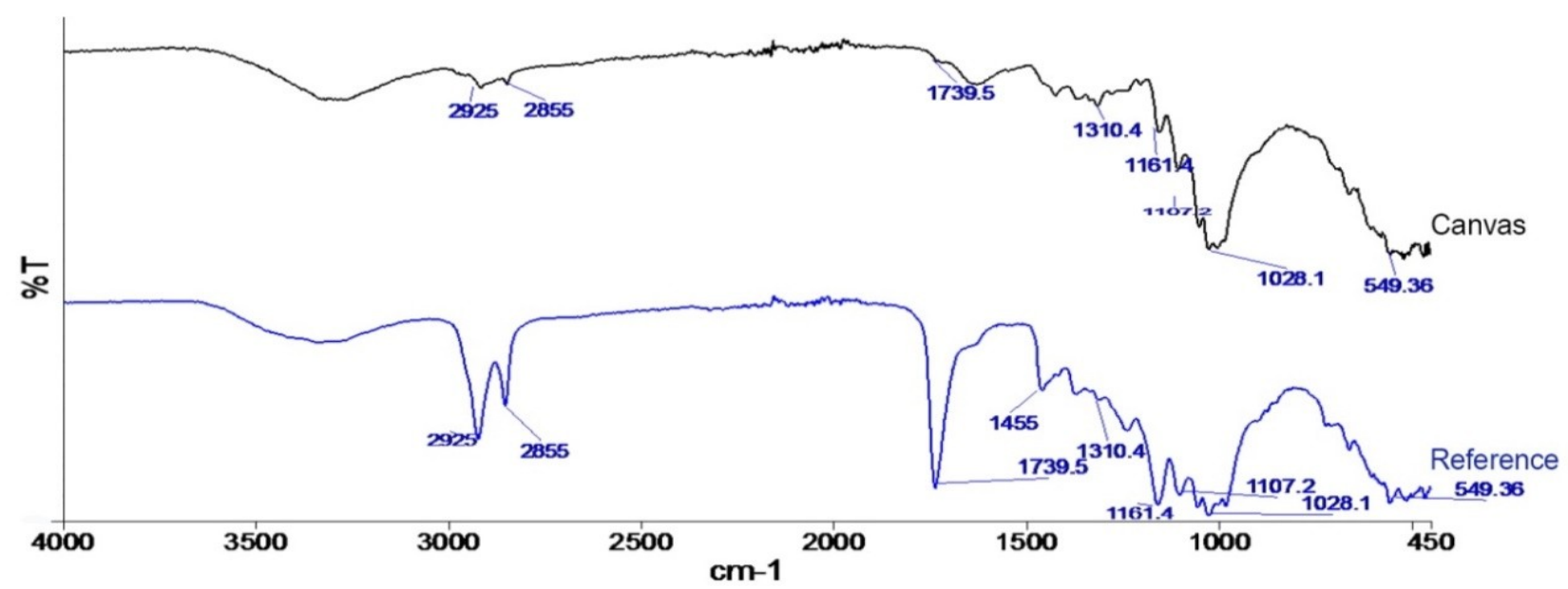

Figure 4. FTIR-ATR spectra of the canvas with paint on it in the Alphabet Revolution oil painting and the reference sample which was prepared by applying linseed oil on the linen canvas.
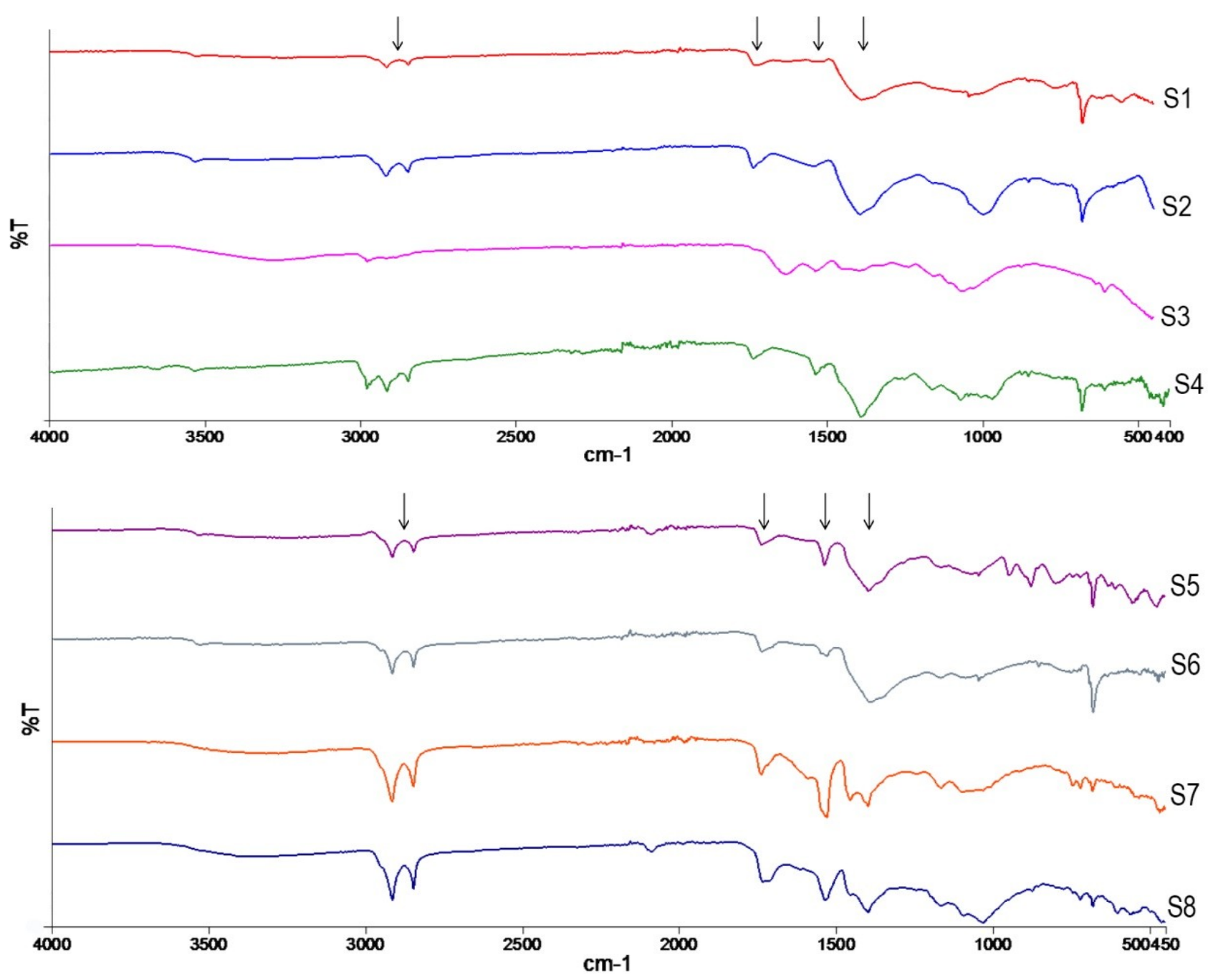


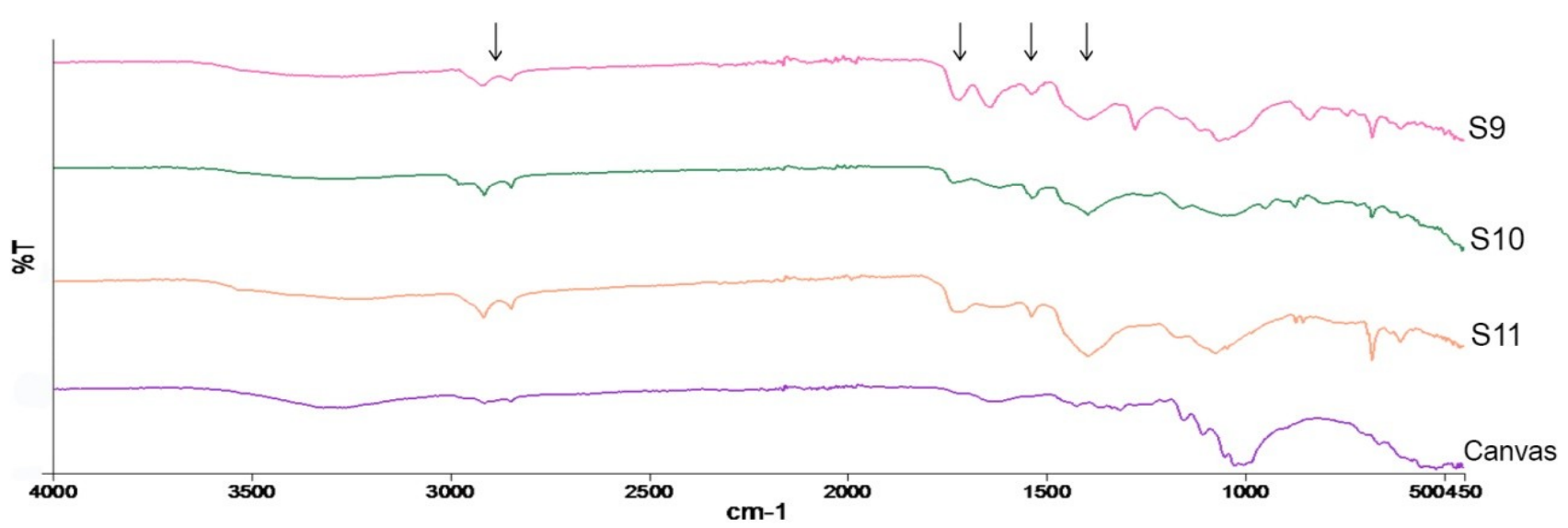

Figure 5. ATR-FTIR comparisons of all the samples in the Alphabet Revolution oil paint.

Table 3. FTIR analyses results: Characteristic bands in all samples in the $400-4000$ region.

\begin{tabular}{|c|c|c|c|c|c|c|c|}
\hline \multirow[t]{2}{*}{ Sample } & \multicolumn{7}{|c|}{ Bond type } \\
\hline & $\begin{array}{c}\mathrm{O}-\mathrm{H} \\
\left(\mathrm{cm}^{-1}\right)\end{array}$ & $\begin{array}{l}\mathrm{C}=0 \\
\text { ester } \\
\text { bond } \\
\left(\mathrm{cm}^{-1}\right)\end{array}$ & $\begin{array}{c}\mathrm{C}-\mathrm{H} \\
\left(\mathrm{cm}^{-1}\right)\end{array}$ & $\begin{array}{l}\text { C-O } \\
\left(\mathrm{cm}^{-1}\right)\end{array}$ & $\begin{array}{c}\mathrm{CO}_{3}{ }^{-2} \\
\text { Carbonate } \\
\left(\mathrm{cm}^{-1}\right)\end{array}$ & $\begin{array}{c}\text { COOH } \\
\text { Carboxylic } \\
\text { acid } \\
\left(\mathrm{cm}^{-1}\right)\end{array}$ & $\begin{array}{c}\text { COO- } \\
\text { carboxylate } \\
\text { Fatty acid } \\
\left(\mathrm{cm}^{-1}\right)\end{array}$ \\
\hline S1 & - & 1729 & $2845-2917$ & 1043 & 1389 & - & - \\
\hline $\mathbf{S 2}$ & - & 1734 & - & 997 & 1395 & $2500-3500$ & 1535 \\
\hline s3 & 3537 & 1733 & $2848-2913$ & - & 1393 & - & 1514 \\
\hline 54 & - & 1737 & $2848-2913$ & - & 1391 & - & 1531 \\
\hline S5 & - & 1739 & $2848-2917$ & - & 1395 & - & 1536 \\
\hline 56 & 3534 & 1738 & $2849-2917$ & - & 1390 & - & 1530 \\
\hline S7 & & 1736 & $2851-2917$ & - & 1397 & - & 1529 \\
\hline 58 & 3300 & 1734 & $2849-2916$ & - & 1397 & & 1535 \\
\hline 59 & 3355 & 1734 & $2850-2923$ & 1044 & 1402 & - & 1531 \\
\hline S10 & - & 1732 & $2851-2920$ & 1040 & 1395 & - & 1542 \\
\hline S11 & & 1727 & $2849-2918$ & & 1394 & - & 1539 \\
\hline Canvas & $\begin{array}{l}3265- \\
3320\end{array}$ & - & $2851-2920$ & 1025 & $\begin{array}{l}1312 \\
1424\end{array}$ & - & - \\
\hline
\end{tabular}

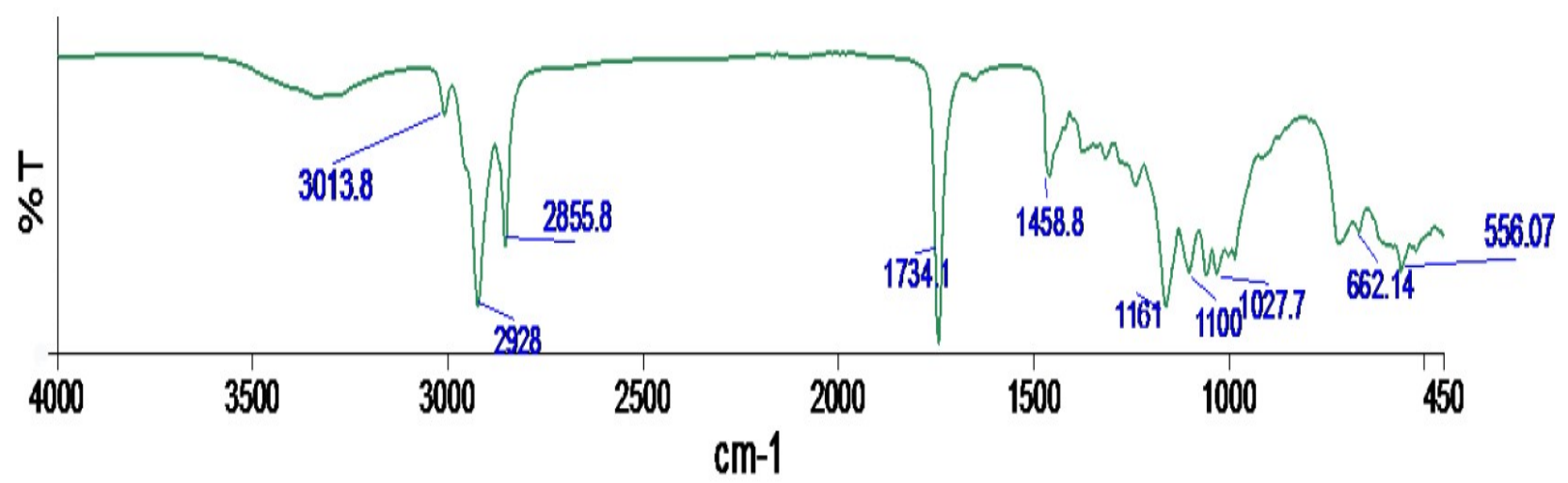

Figure 6. FTIR-ATR spectra of the reference Linseed Oil. 
Table 2. SEM-EDX analysis results of all samples in the Alphabet Revolution oil paint.

\begin{tabular}{|c|c|c|c|c|c|c|c|c|c|c|c|c|c|c|c|c|c|c|}
\hline \multirow{2}{*}{ Sample } & \multirow{2}{*}{ Color } & \multicolumn{17}{|c|}{ Elements and Percentages (\%) } \\
\hline & & $\mathbf{C}$ & $\mathbf{0}$ & $\mathbf{N a}$ & Mg & Al & $\mathbf{S i}$ & $\mathbf{P}$ & $\mathbf{S}$ & $\mathbf{K}$ & $\mathbf{C a}$ & $\mathbf{C r}$ & $\mathbf{F e}$ & Co & Zn & Cd & $\mathbf{B a}$ & $\mathbf{P b}$ \\
\hline S1 & Blue & 21.95 & 20.08 & 0.51 & - & 0.32 & - & - & - & - & - & 0.91 & - & - & 1.33 & - & - & 54.91 \\
\hline $\mathbf{S 2}$ & Blue & 36.41 & 30.46 & 1.90 & 0.56 & 2.43 & 2.27 & - & 2.55 & - & 0.04 & - & - & - & 0.81 & - & - & 22.56 \\
\hline S3 & White & 37.56 & 26.76 & - & - & 0.23 & 0.10 & - & 2.97 & 0.03 & 0.29 & -- & - & - & 26.97 & - & 4.97 & 0.72 \\
\hline S4 & Brown & 34.51 & 30.84 & 1.72 & 0.71 & 2.39 & 4.25 & 0.14 & 3.93 & 1.06 & 6.29 & - & 2.13 & - & 1.73 & - & 1.73 & 8.57 \\
\hline S5 & Green & 20.92 & 18.21 & 0.81 & - & 0.43 & - & - & 0.86 & 1.42 & 0.38 & 6.12 & 0.55 & - & 8.13 & - & 1.18 & 41.00 \\
\hline s6 & Flesh color & 9.99 & 11.63 & 0.33 & - & 0.86 & - & - & 1.25 & 0.02 & 0.31 & - & - & - & 1.29 & 1.17 & 0.04 & 72.80 \\
\hline s7 & Brown & 42.46 & 16.69 & 0.87 & - & 0.98 & 0.65 & - & 0.61 & - & 0.58 & - & 2.61 & - & 1.13 & 0.16 & - & 33.27 \\
\hline S8 & Black & 52.18 & 24.76 & 0.75 & - & 0.67 & 0.38 & 0.14 & 0.67 & - & 1.02 & 0.67 & 0.89 & - & 1.60 & 1.26 & 0.46 & 14.12 \\
\hline s9 & Red & 39.69 & 25.20 & 0.36 & 0.18 & 0.58 & 0.41 & - & 2.11 & 0.25 & 1.85 & - & 0.35 & - & 2.15 & 0.59 & 0.09 & 26.19 \\
\hline S10 & Green & 34.79 & 24.26 & 0.63 & - & 0.19 & 0.07 & - & 0.34 & 0.80 & 1.47 & 4.93 & 0.28 & 0.31 & 8.49 & - & 0.04 & 23.39 \\
\hline 511 & Yellow & 21.59 & 14.57 & 0.19 & - & 0.51 & - & - & 2.67 & 0.08 & 1.63 & - & 0.07 & - & 4.65 & 6.74 & 1.28 & 46.04 \\
\hline
\end{tabular}




\section{HPLC analysis}

Samples 1, 2, and 9 were subjected to HPLC analysis. We could not be able to detect any organic dyes for samples 1 and 2. However, for sample 9 we successfully determined the presence of alizarine and purpurin pigments.
The full HPLC chromatogram of sample 9 is given in Figure 7 and the overlay spectra of alizarine and purpurin references with the corresponding spectra at 27.57 and 28.83 minutes in the HPLC chromatogram of sample 9 are presented in Figure 8 and 9, respectively.

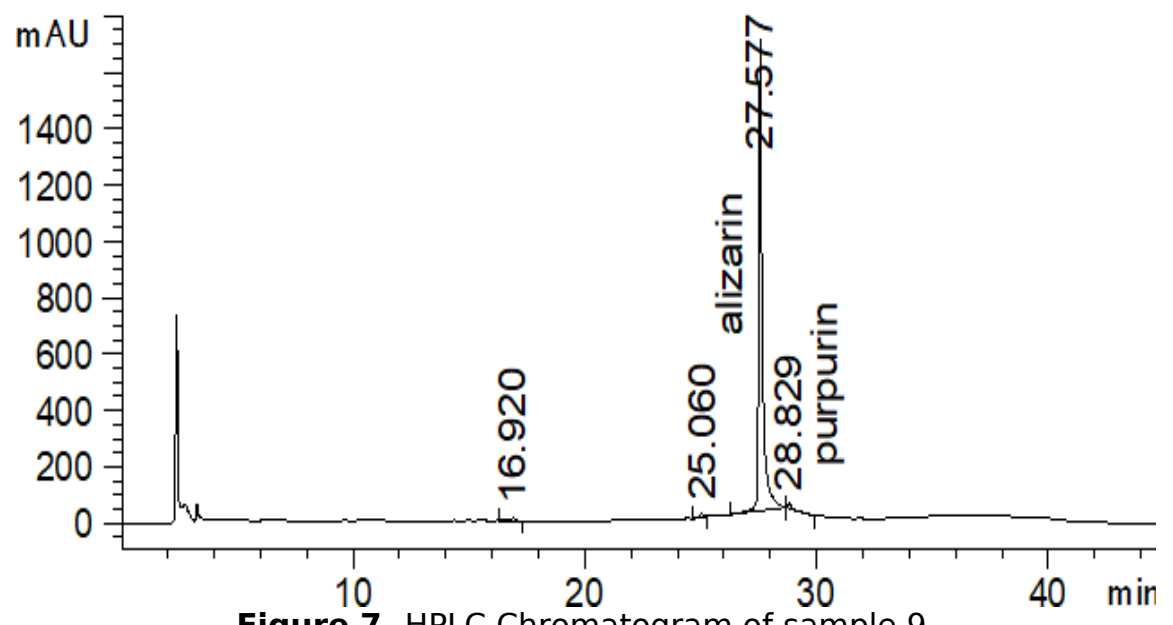

Figure 7. HPLC Chromatogram of sample 9.

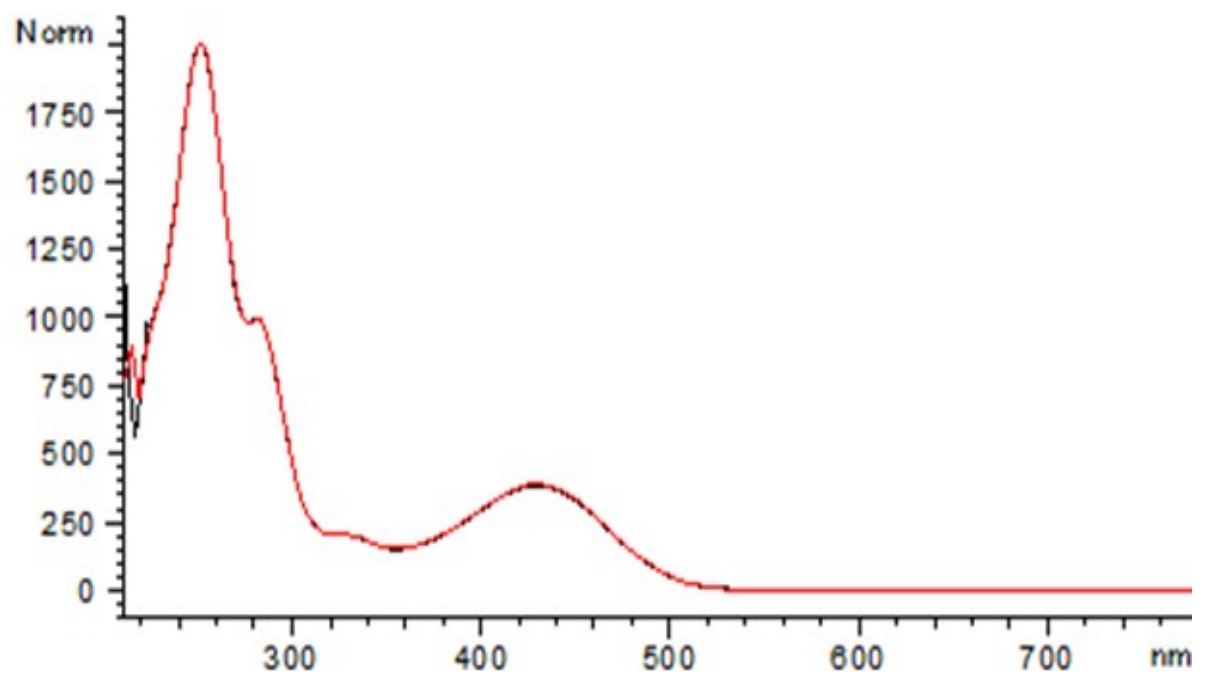

Figure 8. Comparison of the spectrum of alizarin dyestuff with the spectrum obtained at retention time at 27.57 minutes for sample 9. (red line: reference alizarin; black line: sample 9.) 


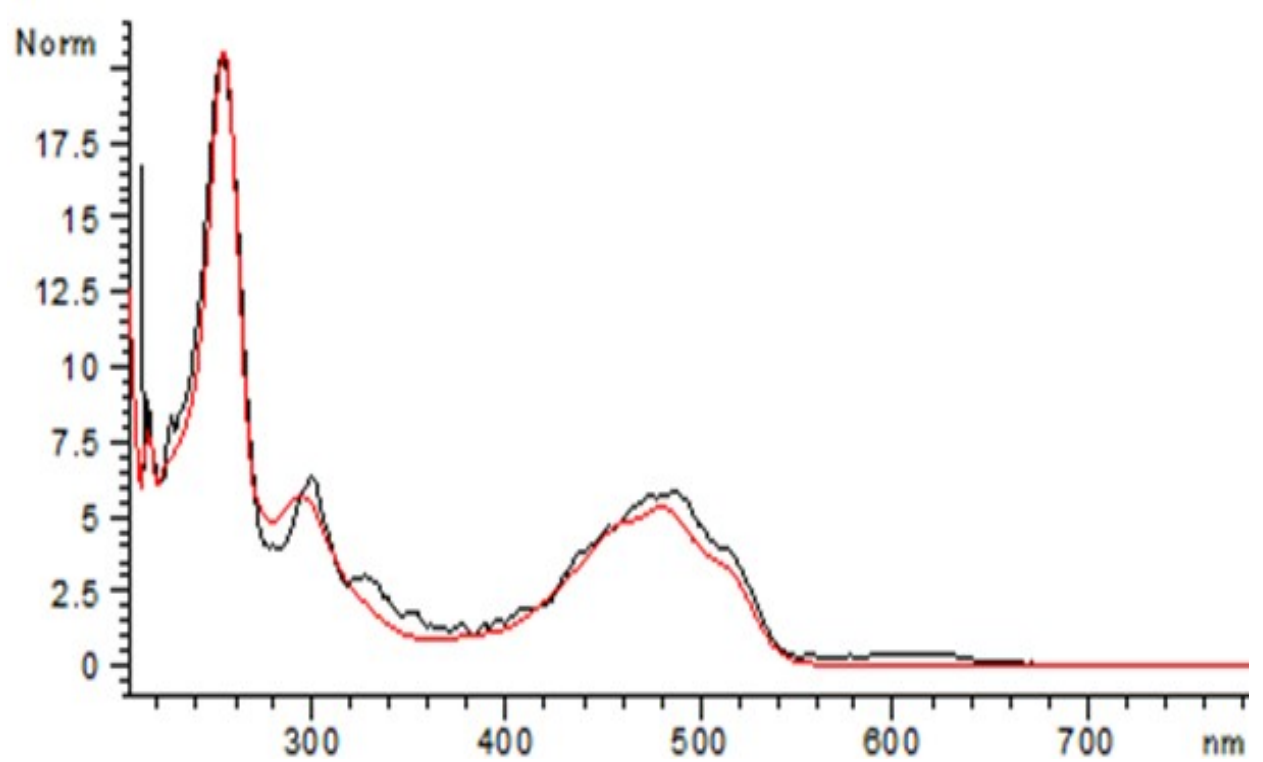

Figure 9. Comparison of the spectrum of purpurin dyestuff with the spectrum obtained at retention time at 28.83 minutes for sample 9. (red line: reference purpurin; black line: sample 9.)

\section{General Evaluation of the Results}

Based on the FTIR-ATR, HPLC analyses and the SEM-EDX results the main components of the samples were determined as follows:

Part S1: SEM-EDX results showed the presence of $\mathrm{Pb}, \mathrm{Zn}$, and $\mathrm{Cr}$. Based on FTIR spectrum the presence of $\mathrm{CO}_{3}{ }^{2-}$ vibrations at $1389 \mathrm{~cm}^{-1}$ and the green color of this section, the pigments in this region can be $\mathrm{PbCO}_{3}, \mathrm{ZnO}$ and $\mathrm{Cr}_{2} \mathrm{O}_{3}$. The band at $678 \mathrm{~cm}^{-1}$ is also a characteristic peak for $\mathrm{PbCO}_{3}$ (7). Moreover, band at 2917 and $2845 \mathrm{~cm}^{-1}$ which are attributed to stretching of $\mathrm{C}-\mathrm{H}$ groups of the binder and a band at $1729 \mathrm{~cm}^{-1}$ which is due to characteristic ester carbonyl were detected in this sample. These findings show that an oil based binder could be used in the painting.

Part S2: In the FTIR spectrum of this sample, a broad band between 3500 and $2500 \mathrm{~cm}^{-1}$ indicates the presence of carboxylic acid groups which can be attributed the hydrolysis of the oil based binder (46) due to aging. Other important bands in this spectrum can be listed as follows: Ester (RCOOR) band at $1734 \mathrm{~cm}^{-1}, \mathrm{CO}_{3}{ }^{2-}$ band at $1395 \mathrm{~cm}^{-1}\left(\mathrm{PbCO}_{3}\right), \mathrm{C}-\mathrm{O}$ at $997 \mathrm{~cm}^{-1}$, which is a characteristic peak for ultramarine blue (21) and the band at $679 \mathrm{~cm}^{-1}\left(\mathrm{PbCO}_{3}\right)$. According to the SEM-EDX result of sample 2; $\mathrm{Na}, \mathrm{Ca}, \mathrm{Al}, \mathrm{Si}$, $S$, $O$ elements were found and no organic dyes were found according to HPLC analysis. The FTIR result of sample 2 is considered to be consistent with the FTIR results of reference ultramarine blue $(21,47)$ and the sample is thought to be synthetic ultramarine blue $\left(\mathrm{Na}_{6}\right.$ $\left.{ }_{10} \mathrm{Al}_{6} \mathrm{Si}_{6} \mathrm{O}_{24} \mathrm{~S}_{2-4}\right)(24)$.

Part 53: The important bands in the FTIR spectrum for this sample were determined as follows: $-\mathrm{OH}$ band at $3537 \mathrm{~cm}^{-1}, \mathrm{C}-\mathrm{H}$ stretching vibrations at 2918 and $2848 \mathrm{~cm}^{-1}$, ester
(RCOOR) band at $1733 \mathrm{~cm}^{-1}$, carboxylate COOband at $1514 \mathrm{~cm}^{-1}$ (which may suggest palmitate oil), $1393 \mathrm{~cm}^{-1}$ and $679 \mathrm{~cm}^{-1}$ for $\mathrm{PbCO}_{3}$, and $\mathrm{Zn}-\mathrm{O}$ at $767 \mathrm{~cm}^{-1}$ (48). EDX revealed the existence of $\mathrm{Pb}, \mathrm{Zn}, \mathrm{Ba}$ elements in this sample. The white color and these findings suggest the presence of Zinc White $(\mathrm{ZnO})$, Barium White $\left(\mathrm{BaSO}_{4}\right)$ and Lead White $\left(\mathrm{PbCO}_{3}\right)$ pigments.

Part S4: This sample produced a similar FTIR spectrum to samples above. It was found to contain $\mathrm{Ca}, \mathrm{Fe}, \mathrm{Pb}, \mathrm{Zn}$ and $\mathrm{Ba}$ according to EDX results. The brown color of this region indicates the presence of $\mathrm{Fe}_{2} \mathrm{O}_{3}$ (hematite) (49) pigment in addition to others such as Zinc White $(\mathrm{ZnO})$, Barium White $\left(\mathrm{BaSO}_{4}\right)$ and Lead White $\left(\mathrm{PbCO}_{3}\right)$. The presence of $\mathrm{Ca}$ could be attributed to presence of Gypsum $\left(\mathrm{CaSO}_{4} \cdot 2 \mathrm{H}_{2} \mathrm{O}\right)$.

Part S5: Different than other spectra $\mathrm{Cr}-\mathrm{O}$ band $476 \mathrm{~cm}^{-1}$ was detected in this sample (22), and the presence of $\mathrm{Cr}$ was also confirmed by EDX measurements.

Part S6: In addition to organic groups the presence of lead was proved by FTIR analysis for this sample. Similar band were found for this sample as detailed above. EDX revealed the presence of $\mathrm{S}, \mathrm{Pb}, \mathrm{Cd}$ and $\mathrm{Zn}$ for this sample. Based on these findings we suggest that a blend of CdS yellow and $\mathrm{Zn}-\mathrm{Pb}$ white were used to obtain flesh color.

Part 57: The FTIR and EDX results suggest that $\mathrm{Fe}_{2} \mathrm{O}_{3}$, CdS yellow and white pigments were mixed to obtain the brown color on this region.

Part 58: The EDX results for this sample gave the highest carbon percentage among other samples. Therefore, the black color of this region is attributed to the presence of carbon black. 
Part 59: HPLC result for this sample showed the presence of organic pigments. Madder lacquer dye (Rubia tinctorum L.) and a mixture of $\mathrm{CdS}$ yellow, $\mathrm{Fe}_{2} \mathrm{O}_{3}$ and $\mathrm{Pb}-\mathrm{Zn}$ white inorganic pigments were found.

Part 510: The main pigment for this green colored region was found as Chromium oxide green. Other spectral evidence show that it is mixed with white pigments and gypsum as well as oil based binder.

Part S11: In addition to similar FTIR bands in all samples a band at $601 \mathrm{~cm}^{-1}$ was detected in the fingerprint region of the FTIR spectrum of this sample. This band is consistent with the reference band of CdS (3). Based on this FTIR result and EDX findings for this sample, it can be said that CdS yellow pigment and white pigments were used for the yellow color of this region.

Canvas: The following bands were detected in the FTIR spectrum of the canvas: at 3265-3320 $\mathrm{cm}^{-1}\left(-\mathrm{OH}\right.$ band), $2851 \mathrm{~cm}^{-1}, 2920 \mathrm{~cm}^{-1}, 1621 \mathrm{~cm}^{-}$ ${ }^{1}\left(-\mathrm{C}=\mathrm{O}\right.$ band), $1424-1321 \mathrm{~cm}^{-1}\left(\mathrm{CO}_{3}{ }^{2-}\right)$ and 1025 $\mathrm{cm}^{-1}$ (C-O). As can be seen from Figure 4, this FTIR spectrum is very similar to the reference spectrum (linen).

Based on all these findings and evaluations the pigments found in the selected sections of the painting are listed in Table 4.

Table 4. Identified pigments in the Alphabet reform painting.

\begin{tabular}{|c|c|c|}
\hline Sample & Color & Detected Pigments \\
\hline S1 & GREEN & $\begin{array}{c}\text { Lead White }\left(\mathrm{PbCO}_{3}\right) \\
\text { Zinc White }(\mathrm{ZnO}) \\
\text { Chromium oxide green }\left(\mathrm{Cr}_{2} \mathrm{O}_{3}\right)\end{array}$ \\
\hline $\mathbf{S 2}$ & BLUE & $\begin{array}{c}\text { Lead White }\left(\mathrm{PbCO}_{3}\right) \\
\text { Zinc White }(\mathrm{ZnO}) \\
\text { Ultramarine blue }\left(\mathrm{Na}_{6-10} \mathrm{Al}_{6} \mathrm{Si}_{6} \mathrm{O}_{24} \mathrm{~S}_{2-4}\right)\end{array}$ \\
\hline S3 & WHITE & $\begin{array}{c}\text { Zinc White }(\mathrm{ZnO}) \\
\text { Barium White }\left(\mathrm{BaSO}_{4}\right) \\
\text { Lead White }\left(\mathrm{PbCO}_{3}\right)\end{array}$ \\
\hline S4 & BROWN & $\begin{array}{c}\text { Zinc White }(\mathrm{ZnO}) \\
\text { Barium White }\left(\mathrm{BaSO}_{4}\right) \\
\text { Lead White }\left(\mathrm{PbCO}_{3}\right) \\
\text { Gypsum }\left(\mathrm{CaSO}_{4} .2 \mathrm{H}_{2} \mathrm{O}\right) \\
\text { Iron oxide }\left(\mathrm{Fe}_{2} \mathrm{O}_{3}\right)\end{array}$ \\
\hline S5 & GREEN & $\begin{array}{c}\text { Lead White }\left(\mathrm{PbCO}_{3}\right) \\
\text { Zinc White }(\mathrm{ZnO}) \\
\text { Barium White }\left(\mathrm{BaSO}_{4}\right) \\
\text { Chromium oxide green }\left(\mathrm{Cr}_{2} \mathrm{O}_{3}\right)\end{array}$ \\
\hline s6 & $\begin{array}{l}\text { FLESH } \\
\text { COLOR }\end{array}$ & $\begin{array}{l}\text { Lead Red }\left(\mathrm{PbO}_{2} .2 \mathrm{PbO}\right) \\
\text { Lead White }\left(\mathrm{PbCO}_{3}\right) \\
\text { Zinc White }(\mathrm{ZnO}) \\
\text { Cadmium yellow }(\mathrm{CdS})\end{array}$ \\
\hline S7 & BROWN & $\begin{array}{l}\text { Lead White }\left(\mathrm{PbCO}_{3}\right) \\
\text { Zinc White }(\mathrm{ZnO}) \\
\text { Iron oxide }\left(\mathrm{Fe}_{2} \mathrm{O}_{3}\right) \\
\text { Cadmium vellow (CdS) }\end{array}$ \\
\hline S8 & BLACK & $\begin{array}{c}\text { Lead White }\left(\mathrm{PbCO}_{3}\right) \\
\text { Zinc White }(\mathrm{ZnO}) \\
\text { Barium White }\left(\mathrm{BaSO}_{4}\right) \\
\text { Gypsum }\left(\mathrm{CaSO} \mathrm{SO}_{4} .2 \mathrm{H}_{2} \mathrm{O}\right) \\
\text { Chromium oxide green }\left(\mathrm{Cr}_{2} \mathrm{O}_{3}\right) \\
\text { Cadmium yellow }(\mathrm{CdS}) \\
\text { Iron oxide }\left(\mathrm{Fe}_{2} \mathrm{O}_{3}\right)\end{array}$ \\
\hline S9 & RED & $\begin{array}{c}\text { Madder (Rubia tinctorum L.) lake } \\
\text { Lead White }\left(\mathrm{PbCO}_{3}\right) \\
\text { Zinc White }(\mathrm{ZnO}) \\
\text { Gypsum }\left(\mathrm{CaSO}_{4} .2 \mathrm{H}_{2} \mathrm{O}\right) \\
\text { Cadmium yellow }(\mathrm{CdS}) \\
\text { Iron oxide }\left(\mathrm{Fe}_{2} \mathrm{O}_{3}\right)\end{array}$ \\
\hline $\mathbf{S 1 0}$ & GREEN & $\begin{array}{c}\text { Lead White }\left(\mathrm{PbCO}_{3}\right) \\
\text { Zinc White }\left(\mathrm{ZnO}^{\prime}\right) \\
\text { Gypsum }\left(\mathrm{CaSO}_{4} .2 \mathrm{H}_{2} \mathrm{O}\right) \\
\text { Chromium oxide green }\left(\mathrm{Cr}_{2} \mathrm{O}_{3}\right) \\
\text { Iron oxide }\left(\mathrm{Fe}_{2} \mathrm{O}_{3}\right)\end{array}$ \\
\hline S11 & YELLOW & $\begin{array}{l}\text { Lead White }\left(\mathrm{PbCO}_{3}\right) \\
\text { Zinc White }(\mathrm{ZnO}) \\
\text { Barium White }\left(\mathrm{BaSO}_{4}\right) \\
\text { Gypsum }\left(\mathrm{CaSO}_{4} .2 \mathrm{H}_{2} \mathrm{O}\right) \\
\text { Cadmium yellow }(\mathrm{CdS})\end{array}$ \\
\hline
\end{tabular}




\section{CONCLUSION}

In this work, the Alphabet Reform painting was analyzed by ATR-FTIR, SEM-EDX and HPLC-DAD analysis methods. The CIE L*a*b* values were also identified. Both organic and inorganic structures, pigments, binders (linseed oil), auxiliary driers ( $\mathrm{Ca}$ and $\mathrm{K}$ elements) and the type of the canvas (linen) used were identified. Red alizarin (madder lake organic pigment) and dark blue ultramarine pigments were detected as the organic pigments while CdS (yellow), $\mathrm{Pb}$ red (flesh color), $\mathrm{PbCO}_{3}$ (white), $\mathrm{ZnO}$ (white), $\mathrm{BaSO}_{4}$ (white), $\mathrm{FeO}$ (brown) and $\mathrm{Cr}_{2} \mathrm{O}_{3}$ (green color) were detected as the inorganic ones.

These results will provide some guidelines for restorers and conservators during restoration and conservation processes. Restorers can apply patching according to the type of canvas. Retouch applications can be easily applied since dyes and pigments are identified. According to the chemical properties of organic and inorganic substances detected on the surface, this study also provides a guidance in the selection of suitable surfactants and solvents for cleaning.

\section{Funding}

This work was supported by Marmara University, Commission of Scientific Research Project (M.U. BAPKO) under grant FEN-C-DRP101018-0537.

CONFLICT OF INTEREST : The authors declare no competing interests.

\section{ACKNOWLEDGMENTS}

We would like to thank to Instructor Abdulkadir Pars from the Faculty of Technology at Marmara University for his support on FTIR analysis.

\section{REFERENCES}

1. Lomax SQ. Phthalocyanine and quinacridone pigments: their history, properties and use. Studies in Conservation. 2005 ; 50:sup-1. 1929. doi:

https://doi.org/10.1179/sic.2005.50.Supplement $\underline{-1.19}$

2. Weerd JV, Loon AV, Boon JJ. FTIR studies of the effects of pigments on the aging of oil. Studies in conservation. 2005; 50:1, 3-22. doi: https://doi.org/10.1179/sic.2005.50.1.3.

3. Feller Robert L, editor. Artists' Pigments A handbook of their history and characteristics Volume 1. London: National Gallery of Art, Washington Archetype Publications; 2012.

4. Roy A, editor. Artists' Pigments A handbook of their history and characteristics Volume 2. London: National Gallery of Art, Washington Archetype Publications; 2012.
5. Fitzhugh EW, editor. Artists' Pigments A handbook of their history and characteristics Volume 3. London: National Gallery of Art, Washington Archetype Publications; 2012.

6. Kasiri MB, Bbaylou AN, Zandkarimi H. Photooxidative stability of a series of red acrylic paints. Progress in color, colorants and coatings. 2014; 177-85. doi:

https://doi.org/https://dx.doi.org/10.30509/pccc. 2013.75834.

7. Zelinska J, Kopecka I, Svobodova E, Milovska S, Hurai V. Stratigraphic EM-EDS, XRF, Raman and FT-IR analysis of multilayer paintings from the Main Altar of the St. James Church in Levoca (Slovakia). Journal of Cultural Heritage. 2018; 33:90-9. doi:

https://doi.org/10.1016/j.culher.2018.03.006.

8. Nasa J, Nodari L, Nardelli F, Sabatini F, Degano I, Modugna F, et al. Chemistry of modern paint media: The strained and collapsed painting by Alexis Harding. Microchemical Journal. 2020 June ; 155:104659. doi: https://doi.org/10.1016/j.microc.2020.104659.

9. Claro A, Melo MJ, Melo JSS, Berg KJ, Burnstock $A$, Montague $M$, et al. Identification of red colorants in van Gogh paintings and ancient Andean textiles by microspectrofluorimetry. Journal of Cultural Heritage. 2010; 11(1) :27-34. doi: https://doi.org/

10.1016/j.culher.2009.03.006.

10. Benetti F, Perra G, Damiani D, Atrei A, Marchettini N. ToF-SIMS characterization of proteinaceous binders in the wall painting "Madonna and Child enthroned with Saints" by Ambrogio Lorenzetti in the St. Augustine Church (Siena, Italy). International Journal of Mass Spectrometry. 2015 Dec;392:111-7. doi: https://doi.org/10.1016/j.ijms.2015.09.018.

11. Kaszowska Z, Malek K, Panczyk M, Mikolajska A. A joint application of ATR-FTIR and SEM imaging with high spatial resolution: Identification and distribution of painting materials and their degradation products in paint cross sections. Vibrational Spectroscopy. 2013; 65: 1-11. doi:

https://doi.org/10.1016/j.vibspec.2012.11.018.

12. Melo HP, Cruz AJ, Valadas S, Cardoso AM, Candeias $A$. The use of glass particles and its consequences in late 16th century oil painting: A Portuguese case based on the analytical results and the technical treatises. Journal of Cultural Heritage. 2020 May;43:261-70.

Doi:

https://doi.org/10.1016/j.culher.2019.11.001.

13. Iwanicka M, Moretti $P$, Oudheusden SV, Sylwestrzak M, Cartechini L, Jan van den Berg K, et al. Complementary use of Optical Coherence 
Tomography (OCT) and Reflection FTIR spectroscopy for in-situ non-invasive monitoring of varnish removal from easel paintings. Microchemical Journal. 2018; 138: 7-18. doi: https://doi.org/10.1016/j.microc.2017.12.016.

14. Rodriguez S H, Appoloni C R, Campos PHOV, Gonçalves B, Kajiya EAM, Molari R, et al. NonDestructive and portable analyses helping the study and conservation of a Saraceni copper plate painting in the Sao Paulo museum art. Microchemical Journal. 2020; 104787. doi: https:// doi.org/https://doi.org/10.1016/j.microc.2020.10 $\underline{4787}$.

15. Costa TG, Silva BFP, Mattos LP, Escorteganha MR, Ritcher FA, Correia MDM, et al. Analysis of the constituent materials of 19th century paintings attributed to Louis-Auguste Moreaux belonging to the Historical Museum of Santa Catarina-Florianopoli, Brazil. Forensic Chemistry. 2019; 100177. doi:

https://doi.org/https://doi.org/10.1016/j.forc.201 9.100177.

16. Gil M, Manso M, Pessanha S, Manhita A, Cardoso A, Nunes $M$, et al. Old masters under the microscope.Technical and material comparison of a 17th C. mural and panel painting assigned to Jose de Escovar in Southern Portugal. Microchemical Journal. 2020; 104396. https://doi.org/10.1016/j.microc.2019.104396.

17. Nevin A, Comelli D, Osticioli I, Toniolo L, Valentini G, Cubeddu R. Assesment of the ageing of triterpenoid paint varnishes using fluorescence, Raman and FTIR spectroscopy. Analytical and Bioanalytical. Chemistry 2009; 395:21392149. doi: https://doi.org/10.1007/s00216-0093005-4.

18. Ciofini D, Striova J, Camaiti M, Siano S. Photo-oxidative kinetics of solvent and oil-based terpenoid varnishes. Polymer Degredation and Stability. 2015; 30124-5. doi: https://doi.org/10.1016/j.polymdegradstab.2015 .11 .002 .

19. Rie E. The Influence of varnishes on the appearance of paintings. Studies in Conservation. 1987; pp.1-13. doi: https://doi.org/10.1179/ sic.1987.32.1.1.

20. Karadag R, Dolen E. Examination of Historical Textiles With Dyestuff Analyses by TLC and Derivative Spectrophotometry. Turkısh Journal of Chemistry. 1997; 21: 126-33. Url:

https://journals.tubitak.gov.tr/chem/issues/kim97-21-2/kim-21-2-9-96058.pdf.

21. Doleżyńska-Sewerniak E, Klisińska-Kopacz A. A characterization of the palette of Rafał Hadziewicz (1803-1886) through the following techniques: Infrared false colour (IRFC), XRF, FTIR, RS and SEM-EDS. Journal of Cultural Her- itage. 2019 Mar;36:238-46. doi:

https://doi.org/10.1016/j.culher.2018.09.001.

22. Vahur S, Teearu A, Leito I. ATR-FT-IR spectroscopy in the region $550-230 \mathrm{~cm}-1$ for identification of inorganic pigments. Spectrochimica Acta Part A: Molecular and Biomolecular Spectroscopy. 2010; 75: 1061-72. doi: https://doi.org/10.1016/j.saa.2009.12.056.

23. Van Loon A, Boon J.J. Characterization of the deterioration of bone black in the 17 th century Oranjezaal paintings using electron-microscopic and micro-spectroscopic imaging techniques. Spectrochimica Acta Part B 59. 2004; 1601-9. doi:

https://doi.org/10.1016/j.sab.2004.03.0 21.

24. Monico L, Rosi F, Miliani C, Daveri A, Brunetti B. G. Non-invasive identification of metal-oxalate complexes on polychrome artwork surfaces by reflection mid-infrared spectroscopy. Spectrochimica acta Part A: Molecular and Biomolecular Spectroscopy 116. 2013; 270-80. doi:

https://doi.org/10.1016/j.saa.2013.06.084.

25. Vetter W, Schreiner M. Characterization of pigment-bındıng media systems-comparison of non-invasive in-situ reflection FTIR with transmission FTIR microscopy. www.ePRESERVATIONScience.org 2011; 8, 10-22. url: https://www.researchgate.net/profile/Manfred_S chreiner/publication/

312415149 Identification and Preservation of Cultural_Heritage/links/

5a4f528daca2726172bc8a95/Identification-andPreservation-of-Cultural-Heritage.pdf.

26. Newman R. Some application of Infrared Spectroscopy in the examination of painting materials. Journal of the American Institute for Conservation. 1980;19: 42-62. doi: https://doi.org/10.1179/019713679806028977.

27. Zangrando R, Piazza R, Cairns W. R. L, Izzo F.C, Vianello A. Quantitative determination of un-derivatised amino acids in artistic mural paintings using high-performance liquid chromatography/electrospray ionization triple quadrupole mass spectrometry. Analytica Chimica Acta. 2010; 675: 1-7. doi:

https://doi.org/10.1016/j.aca.2010.06.045.

28. Marras S, Pojana G, Ganzerla R, Marcomini A. Study and characterization of mural paintings from XIX century in a noble Venetian (Italy) palace. Microchemical Journal. 2010;96: 397405. doi:

https://doi.org/10.1016/j.microc.2010.07.003.

29. Costa TG, Ritcher FA, Correia M, Escorteganha MR, Santiago AG. Multi-technical analysis as a tool to investigate structural species in the "replica" of First Mass in Brazil 
painting by Sebastião Vieira Fernandes. Journal of Molecular Structure. 2016; 196-204. doi: https://doi.org/10.1016/j.molstruc.2016.05.019.

30. Saverwyns S, Currie C, Lamas-Delgado E. Macro X-ray fluorescence scanning (MA-XRF) as tool in the authentication of paintings.

Microchemical Journal. 2018;137: 139-47. doi: https://doi.org/10.1016/j.microc.2017.10.008.

31. Giorgi L, Nevin A, Nodari L, Comelli D, Alberti R. In-situ technical study of modern paintings part 1: The evolution of artistic materials and painting techniques in ten paintings from 1889 to 1940 by Alessandro Milesi (1856-1945). Spectrochimica Acta Part A: Molecular and Biomolecular Spectroscopy. 2019;219: 530-8. doi:

https://doi.org/10.1016/j.saa.2019.04.083.

32. Deveoglu O, Torgan E, Karadag R. The characterization by liquid chromatography of lake pigments prepared from European buckthorn (Rhamnus cathartica L.). Pigment \& Resin Technology. 2012 ; 41: 331-8. doi: https:// doi.org/10.1108/03699421211274234.

33. Deveoglu O, Erkan G, Torgan, E, Karadag R. The evaluation of procedures for dyeing silk with buckthorn and walloon oak on the basis of colour changes and fastness characteristics. Coloration Technology. 2013; 129: 223-31. doi: https://doi.org/10.1111/cote.12023.

34. Deveoglu O, Karadag R, Torgan E, Yildiz Y. Examination of dyeing properties of the dyed cotton fabrics with barberry (Berberis vulgaris L.). Journal of Natural Fibers. 2018;1809-98. 1544-0478. doi:

https://doi.org/10.1080/15440478.2018.155814 3.

35. Yasukava Akemi, Chida Ayumi, Yoji Kato, Kasai Miki. Dyeing silk and cotton fabrics using natural blackcurrants. Sage Journals. 2017; 87:2379-87. doi:

https://doi.org/10.1177\%2F0040517516671125.

36. Deveoglu O, Karadag R, Yurdu T. Qualitative HPLC determination of main anthraquinone and lake pigment contents from dactylopius coccus dye insect. Chemistry of Natural Compounds. 2011; 47: No.1. doi:

https://doi.org/10.1007/s10600-011-9842-3.

37. Deveoglu O, Torgan E, Karadag R. Identification by RP-HPLC-DAD of natural dyestuffs from lake pigments prepared with a mixture of weld and dyer's oak dye plants. Journal of Liquid Chromatography \& Related Technologies. 2012; 35: 331-42. doi: https://doi.org/10.1080/10826076.2011.601487.

38. Deveoglu O, Cakmakcı E, Taskopru T, Torgan E, Karadag R. Identification by RP-HPLCDAD, FTIR, TGA and FESEM-EDAX of natural pigments prepared from Datisca cannabina L. Dyes and Pigments. 2012; 94: 437-42. doi: https://doi.org/10.1016/j.dyepig.2012.02.002.

39. Karadag R, Torgan E, Taskopru T, Yildiz, Y. Characterization of dyestuffs and metals from selected 16-17th- century ottoman silk brocades by RP-HPLCDAD and FESEM-EDX. Journal of Liquid Chromatography \& Related Technologies. 2015; 38:5 591-9. doi: https://doi.org/10.1080/10826076.2014.922476.

40. Pintus V, Wei S, Schreiner M. Accelerated UV ageing studies of acrylic,alkyd, and polyvinyl acetate paints: Influence of inorganic pigments. Microchemical Journal. 2016; 124: 949-61. doi: https://doi.org/10.1016/j.microc.2015.07.009.

41. Rosi F, Daveri A, Moretti P, Brunetti BG, Miliani C. Interpretation of mid and near-infrared reflection properties of synthetic polymer paints for the non-invasive assessment of binding media in twentieth-century pictorial artworks. Microchemical Journal. 2016; 124: 898-908. doi: https://doi.org/10.1016/j.microc.2015.08.019.

42. Banti A, La Nasa J, Tenorio AL, Modugno F, Jan KVD, Ormsby B, et al. A molecular study of modern oil paintings: investigating the role of dicarboxylic acids in the water sensitivity of modern oil paints. Royal Society of Chemistry Advances. 2018; 8: 6001-12. doi: https://doi.org/ 10.1039/C7RA13364B.

43. Şahinbaşkan B. Y, Karadag R, Torgan E. Dyeing of silk fabric with natural dyes extracted from cochineal (Dactylopius coccus Costa) and gall oak (Quercus infectoria Oliver). Journal of Natural Fibers. 2017. doi:

https://doi.org/10.1080/15440478.2017.134970 8.

44. Karadag R, Yurdun T. Dyestuff and Colour Analyses of the Seljuk Carpets in Konya Ethnography Museum. The International Institute for Conservation of Historic \& Artistic Works. 2010. doi:

https://doi.org/10.1179/sic.2010.55.Supplement $-2.178$

45. Nayak R, Houshyar S, Khandual A, Padhye R, Fergusson S. Handbook of Natural Fibres (Second Edition) Volume 1: Types, Properties and Factors Affecting Breeding and Cultivation In: Kozlowski R. M, Talarczyk M. M. (editors). Chapter 14: Identification of natural textile fibres . 2020; pp. 503-34. doi: https://doi.org/10.1016/B978-0-12-8183984.00016-5.

46. Sanches D, Ramos AM, Coelho JFJ, Costa CSF, Vilarigues M, Melo MJ. Correlating thermophysical properties with the molecular composition of 19th century chrome yellow oil paints. Polymer Degradation and Stability. 2017; 138: 201-11. doi: 
https://doi.org/10.1016/j.polymdegradstab.2017 .02 .010 .

47. Izzo FC. 20th Century Artist's Oil Paints; A Chemical-Physical Survey.Thesis for: PhD in Chemical Science-Conservation Science. 2011May. Url: http://hdl.handle.net/10579/1100.

48. Maryse M. dottorato di ricerca Application of FTIR microscopy to cultural heritage materials.
2009. doi:

https://doi.org/10.6092/unibo/amsdottorato/140 $\underline{4}$.

49. Delamare F, Guineau B. Les matériaux de la couleur. Paris: Gallimard; 1999. 159 p.

(Découvertes Gallimard). Url:

https://www.bcin.ca/bcin/detail.app?id=192315. 